\title{
Women and Superannuation: Work Until You Drop?
}

\author{
Jo Vu and James Doughney \\ Victoria University, Australia
}

\begin{abstract}
Superannuation is becoming an increasingly important source of retirement income. However, women in Australia face a significant barrier in accumulating superannuation entitlements because of their positions in the paid and unpaid workforce. When in paid work, women occupy lower positions, have more career breaks due to care responsibilities and have more part-time and casual employment. Many women, of course, do not work outside the home, and a smaller proportion of women engage in paid employment than do men. Consequently women have lower incomes, less wealth and less generous retirement benefits. Our analysis of the Survey of Employment Arrangements and Superannuation and other Australian Bureau of Statistics data, together with data published by the Australian Prudential Regulatory Authority, reveals that dramatic policy initiatives will be needed to improve women's access to retirement resources. Such policies do not apply only to superannuation but must address women's positions in the paid workforce and their care responsibilities.
\end{abstract}

\section{Keywords}

Retirement, Women, Intergeneration, and Superannuation.

\section{Introduction}

Economic security is central to achieving equity for women. As today's generations of Australian women age the two main sources of support income on which they will rely are the age pension and the superannuation assets they (and or their partners) accumulate throughout their lives. 'Superannuation refers to a long-term savings arrangement which operates primarily to provide income for retirement.' (ABS 2002a) Since the 1980s, Commonwealth Government retirement policy has privileged individual superannuation over the state funded age pension, which increasingly is seen as a safety net.

Both the age pension and superannuation are claims on future production. Such claims obviously provide financial security when they fall due upon retirement, but they also provide a sense of economic and social security now. As the pension becomes relatively less significant, those who rely on it exclusively or mainly will feel less secure now because they will in reality be less secure in the future.

Copyright (C) 2009 Victoria University. This document has been published as part of the Journal of Business Systems, Governance and Ethics in both online and print formats. Educational and non-profit institutions are granted a nonexclusive licence to utilise this document in whole or in part for personal or classroom use without fee, provided that correct attribution and citation are made and this copyright statement is reproduced. Any other usage is prohibited without the express permission of the
Conversely those with reasonable superannuation claims and appreciating nonfinancial assets, especially the family home, will be more secure in the future and will feel correspondingly more secure now.

Security in both its physical (external) and psychological (internal) aspects becomes an increasingly important feature of our general wellbeing as we age. Our need for security 
parallels our weakening physical powers and diminished income-earning capacities. Partly we can offset our growing dependency by maintaining secure sources of wealth and income as we depart the paid workforce. Economic security, however, while not an end in itself is an indispensable means: its absence forces us to attend to purely instrumental economic wellbeing, and this unambiguously diminishes our capability to lead free and flourishing lives.

We make these reasonably obvious points to emphasise the consequences of the fact that the economic resources needed for human wellbeing are unequally distributed. Women, even in relatively prosperous societies like our own, have lower average levels of access to the economic requirements of wellbeing. The consequences are readily apparent. Women's need for security is greater, and women are less able to offset the increased dependency that comes with age than are men. The unequal distribution of resources needed for wellbeing in retirement is especially unjust because, while the population is ageing generally, women live longer than do men. Their need is correspondingly greater. 'Over the past 20 years ... life expectancy at birth improved by 6 years for males, to 78 years, and 4 years for females, to 83 years.' (ABS 2006a)

While population ageing will not create the economic 'crisis' many currently suppose it will (Doughney \& King 2006; Doughney 2005b), it nevertheless does have important implications for resource allocation, equity and the possibility that older people may age well. The phenomenon of ageing requires that we create proactive plans, policies and strategies to ensure that the various dimensions of ageing well can be maximised and are achievable. Gender is one of those dimensions. The battle for equality does not cease at retirement.

In the second section we analyse in three parts the most recent national data from the Australian Bureau of Statistics (ABS), the Reserve Bank of Australia (RBA) and the Australian Prudential Regulatory Authority (APRA). The first is women's current access to economic resources via the labour market and remuneration. The second validates our assertion above that Australia and other English-speaking countries are relying more on superannuation and related forms of individual retirement saving rather than on the age pension. The third is that women's access to superannuation resources is significantly worse than that of men. The data reveal that dramatic policy initiatives will be needed to improve women's access to retirement resources. Such policies do not apply only to superannuation but must address women's positions in the paid workforce and their care responsibilities. The policy issues we take up in the third section.

\section{Influences on Women's Retirement Resources}

\section{(i) Women's disadvantage in the paid labour force}

Despite the increase in women's participation in Australia's paid workforce, women are far more likely to work part-time and to work fewer hours than do men. Even when working full-time, women's employment continues to be concentrated in lower level jobs (Doughney \& Leahy 2006), and their average earnings amount to only 85 per cent of male average full-time adult ordinary time earnings. These results are depicted in charts 1-3 below. 
Chart 1: Female and male labour force participation Australia 1983-2005

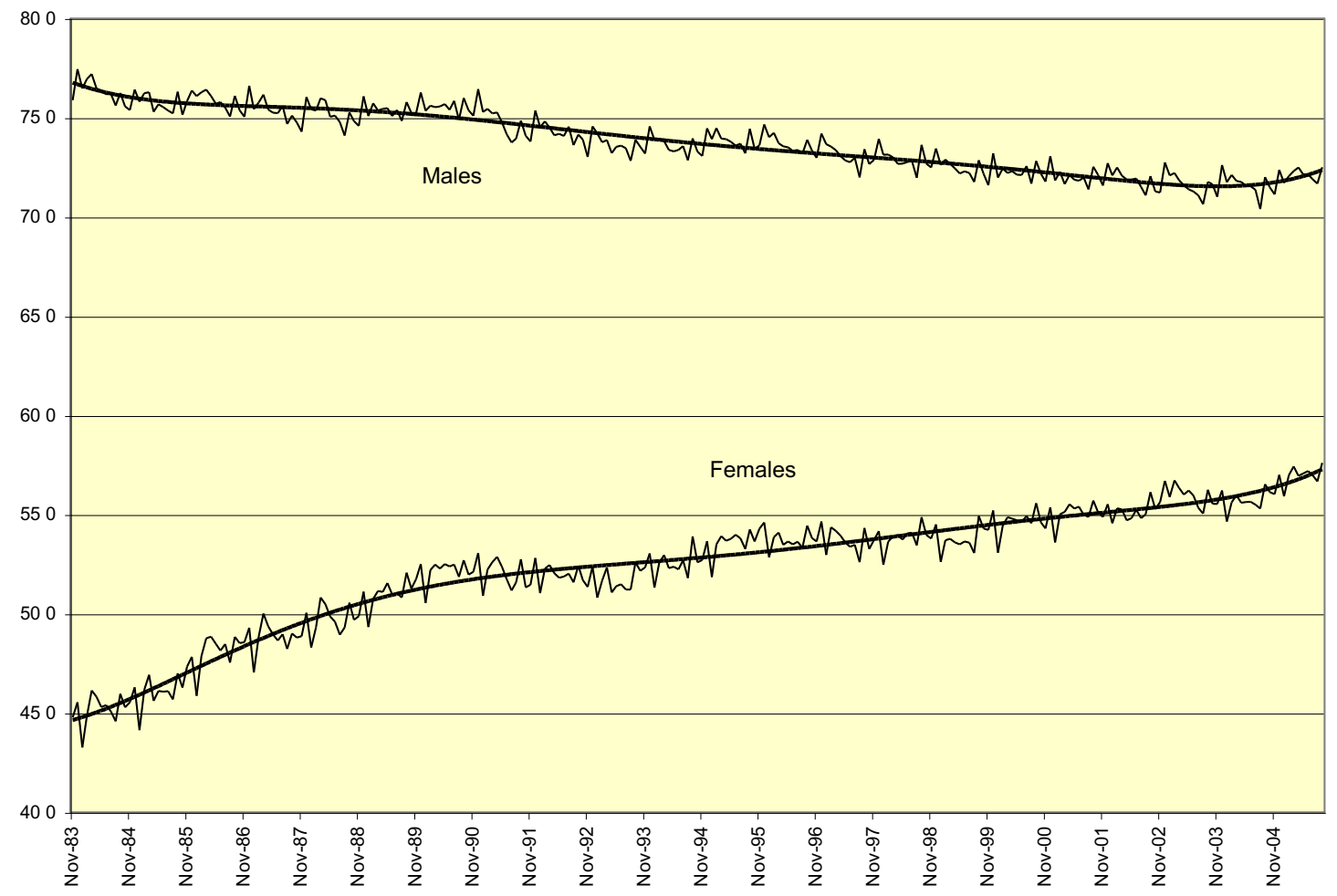

Source: ABS (2005c, Cat. no. 6291.0.55.001)

Chart 2: Female and male part-time work Australia 1983-2005

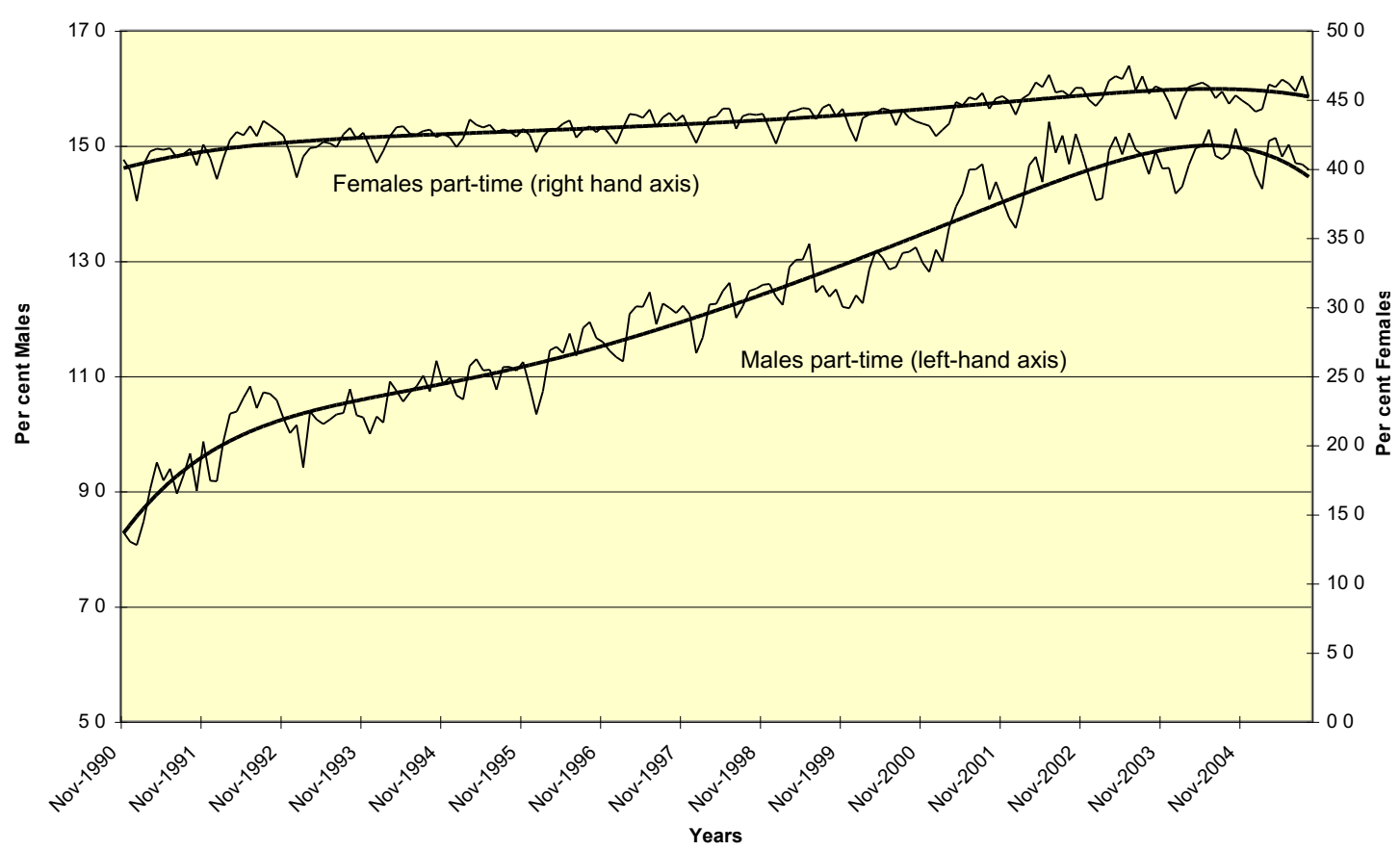

Source: ABS (2005c, Cat. no. 6291.0.55.001) 
Chart 3: Female earnings as a percentage of male earnings Australia 1983-2005

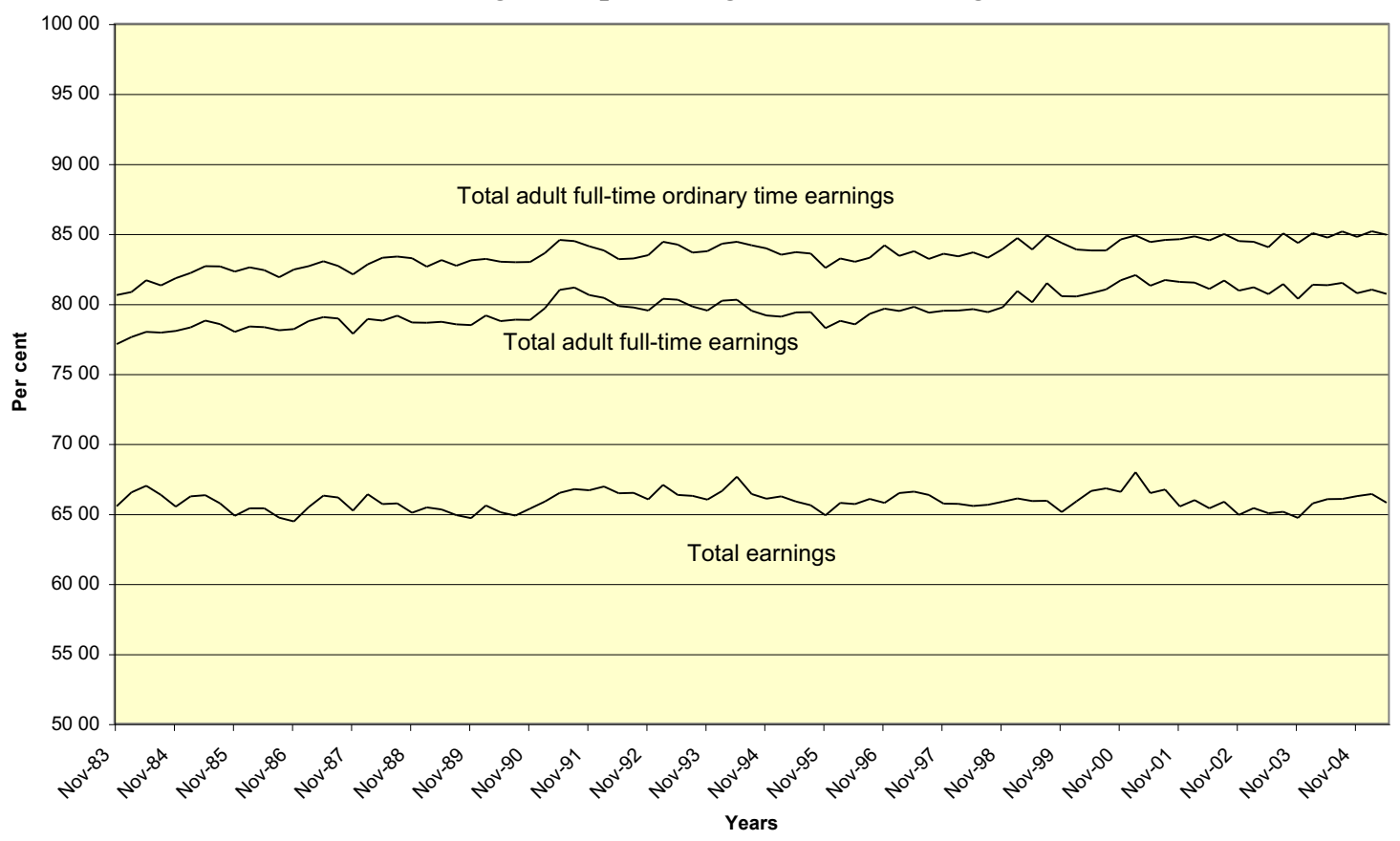

Source: ABS (2005d, Cat. no. 6302.0)

Women's average labour force participation has increased from below 45 per cent in 1983 to about 57 per cent today. It grew more rapidly in the 1980s than it has done in the 1990s. However, a considerable proportion of this growth has been in part-time work. Chart 2 shows that today about 45 per cent of jobs held by women are part time. This compares with about 15 per cent for men. This explains why women's total earnings, the lowest of the three lines in chart 3 have remained at about two-thirds the level of men's.

Earning a lower income compared with men means that women's retirement savings in the form of superannuation contributions are correspondingly lower. Women from Non-English Speaking Backgrounds (NESB) are at most risk regarding superannuation contributions. Unemployment rates are higher among them, and those in employment are more likely to work in manual, low-paid jobs ( 83 per cent). Women who are sole parents are also particularly disadvantaged, and in 2002 the majority of lone parents were women (Doughney et al., 2003).

\section{(ii) Superannuation and retirement income in Australia}

In Australia the principal form of retirement savings by individuals is superannuation contributions for the employee paid by the employer. Ellis Connolly and Marion Kohler describe the history of this development in a 2004 RBA discussion paper:

Superannuation has been used in Australia as a policy instrument to increase retirement incomes and reduce reliance on the age pension (which is provided by the government) ... In 1986 compulsory superannuation was introduced in Australia. The system initially applied to employees on Federal awards, with 3 per cent of their earnings saved in superannuation funds in lieu of wage rises. The system was extended to apply to most employees in 1992 under the Superannuation Guarantee Charge (SGC), with the contribution rate gradually raised to its current level of 9 per cent of earnings and coverage increased to 90 per cent of employees. Perhaps not surprisingly, households' superannuation assets as a proportion of GDP almost quadrupled in Australia over the last 20 years (Figure 1), and are now the second largest component of household wealth after non-financial assets, which comprise mostly housing. (2004, p. 2; citing Bateman, Kingston and Piggott 2001, p. 210; Commonwealth Treasury of Australia 2001) 
Connolly and Kohler also note that 'the growth in superannuation funds (or their equivalent) was an experience shared by the US and the UK' (2004, p. 2).

In 2004-5 aggregate employer contributions were $\$ 42.4$ billion, while individuals' contributions totalled $\$ 23.5$ billion (APRA 2006). Currently more than 300,000 retiree households receive superannuation payments, while more than one million households receive government retirement pensions. Note that it is possible to receive the age pension or part-pension and superannuation payments. The mean weekly pension payment to households in 2003-4 was \$369, compared with the mean superannuation payment of $\$ 870$ (ABS 2005e). Those with superannuation payments only are twice as well off (in income terms) as are those with the pension only, as the data in table 2 below suggest (ABS 2001a, 2001b). Note that the ABS warns that superannuation income may be under-reported in the latter survey-based set of data.

Unlike superannuation payments, the age pension does not derive from a form of saving (i.e. saving in the form of pre-retirement superannuation contributions). A pension is a government transfer at the time of its payment. However, both pensions and superannuation are claims on future social or national income. The former is a future social claim, insofar as it is an entitlement extended to all persons older than a given age with assets and incomes less than prescribed amounts. The latter may be a defined benefit in the future based on contribution level (of employer and individual) and salary level. Alternatively, it may be a progressively quantified future entitlement based on contribution level, asset growth over time and selection of asset types, proportionate mix of assets and risk strategy.

Superannuation may be paid in the future as a lump sum, an annuity-type payment (superannuation pension) or some mix of the two. In 2004-5, $\$ 19.6$ billion was paid out in lump sums, while $\$ 10.4$ billion was paid in the form of superannuation pensions. The total paid of $\$ 30$ billion compares with total government age pension and related war-service or disability payments for 2004-5 of \$23.4 billion (ABS 2006). Assets held by superannuation funds have grown dramatically, as chart 4 shows. Currently $\$ 446$ billion are held in accumulation funds, $\$ 19.3$ billion in defined benefit funds, $\$ 253.2$ billion in hybrid funds and $\$ 43.2$ billion in annuities and life office reserves: a total of $\$ 761.9$ billion.

The important distinction between the age pension and superannuation is that the pension is not dependent on a person's lifetime or pre-retirement income. Superannuation savings, however, are a direct function of person's lifetime or pre-retirement income. Given the facts concerning women's salaries and working lives we presented in the previous section, this functional relationship puts women at a clear disadvantage.

Table 2: Mean household weekly income vs. forms of retirement income Australia 2003-4

\begin{tabular}{|c|c|c|c|}
\hline Mean income & $\begin{array}{c}\text { Wages and } \\
\text { salaries } \\
\$\end{array}$ & $\begin{array}{c}\text { Retirement } \\
\text { pensions } \\
\$\end{array}$ & $\begin{array}{c}\text { Super- annuation/ } \\
\text { annuity income } \\
\$\end{array}$ \\
\hline Gross household income (household weighted) & 1,493 & 369 & 870 \\
\hline $\begin{array}{l}\text { Income tax and Medicare levy payable (household } \\
\text { weighted) }\end{array}$ & 321 & 1 & 133 \\
\hline Disposable household income (household weighted) & 1,172 & 368 & 737 \\
\hline & \multicolumn{3}{|c|}{$\%$ wages and salaries } \\
\hline Gross household income (household weighted) & 100.0 & 24.7 & 58.3 \\
\hline $\begin{array}{l}\text { Income tax and Medicare levy payable (household } \\
\text { weighted) }\end{array}$ & 100.0 & 0.4 & 41.5 \\
\hline \multirow[t]{2}{*}{ Disposable household income (household weighted) } & 100.0 & 31.4 & 62.9 \\
\hline & \multicolumn{3}{|c|}{$\%$ superannuation/annuity income } \\
\hline Gross household income (household weighted) & n.a. & 42.4 & 100.0 \\
\hline $\begin{array}{l}\text { Income tax and Medicare levy payable (household } \\
\text { weighted) }\end{array}$ & n.a. & 1.0 & 100.0 \\
\hline Disposable household income (household weighted) & n.a. & 49.9 & 100.0 \\
\hline
\end{tabular}
ABS (2005e, Cat. no. 6523.0) 
Chart 4: Assets held by Australian superannuation funds 1983-2005 \$ billion

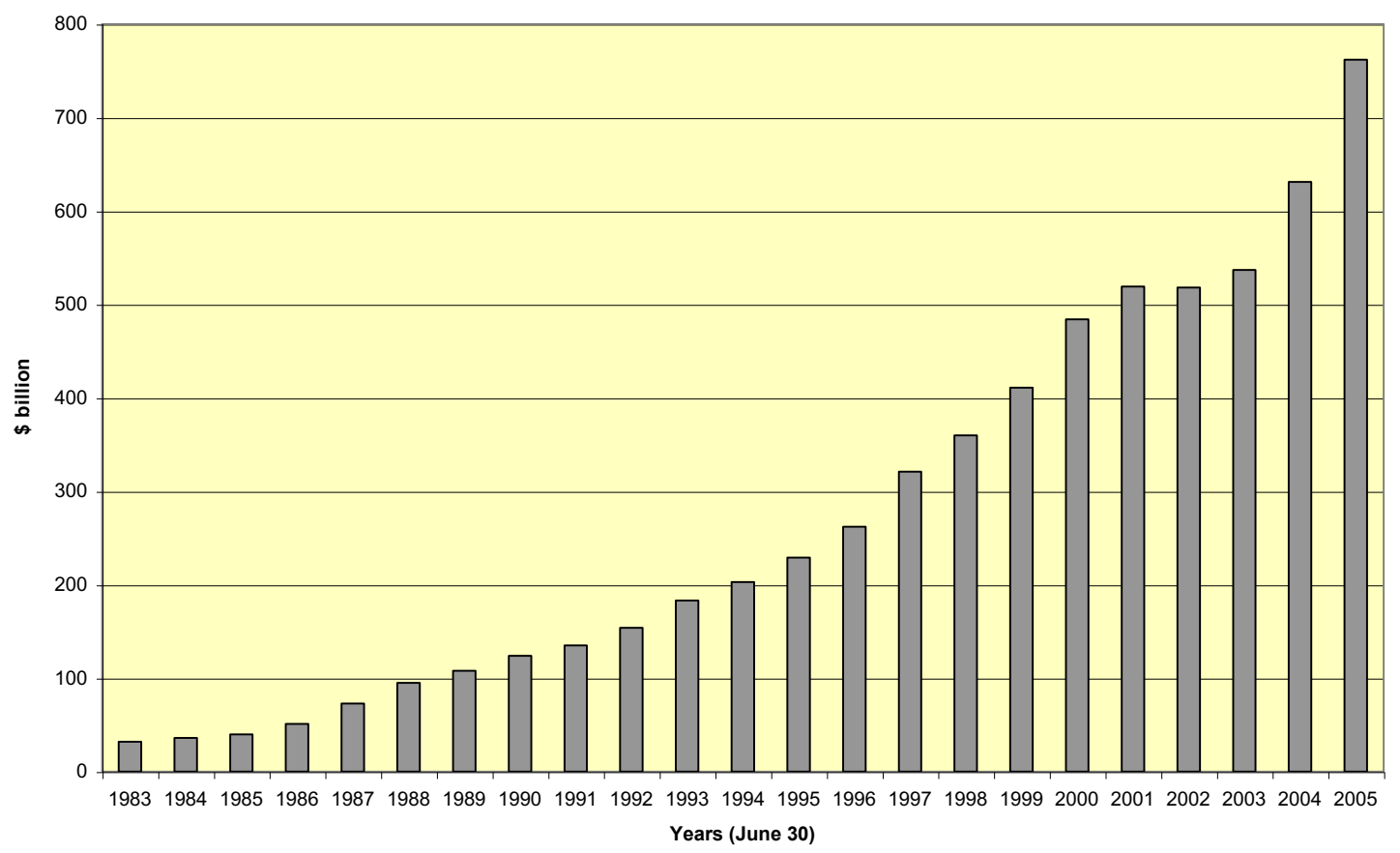

Source: APRA (2006)

\section{(iii) Women's disadvantage in saving for retirement}

Women's average working lives are shorter than are men's, and they are also interrupted due to childbearing, child-rearing and other care responsibilities (Olsberg 2004). Hence, women's capacity to accumulate retirement savings is impaired. Career interruptions also tend to lead to deterioration in women's labour market and promotional opportunities. The points are reinforced in findings of the ABS:

As employer superannuation contributions are a proportion of employee earnings, and female employees tend to earn less than male employees, women generally receive smaller employer contributions. They also have less personal income to contribute to superannuation than men resulting in lower superannuation savings overall. (ABS 2002a)

The ABS also makes the point that 'women's generally younger retirement age and longer life expectancy' means that 'women may need to accrue more superannuation savings than men to maintain a similar standard of living throughout their longer retirement years'. (ABS 2002a) As Ross Clare notes, this is almost to state the 'bleeding obvious', but even stating the bleeding obvious clearly can help in targeting policy responses more precisely (2004, p. 2).

While more than 90 per cent of all Australian employees are covered by superannuation, women employees hold the minority (45 per cent) of superannuation accounts (ABS 2001b). More importantly, according to the ABS Survey of Employment Arrangements and Superannuation (2001b, SEAS), women's median account balances were 47.6 per cent of men's. More recent data, drawn from the August 2004 Employee Earnings, Benefits and Trade Union Membership survey (ABS 2005f), shows that women's superannuation concentration follows their employment concentration: in part-time work and in lower paid jobs (see table 3). Chart 5 illustrates the effects more clearly. For women employees to be concentrated at the left-hand side of chart 5 means that their retirement claims will be lower because those future claims are a direct function of today's income. 
Table 3: Superannuation coverage of employees by average weekly earnings Australia $2004 \%$

\begin{tabular}{|c|c|c|c|c|c|c|c|c|c|}
\hline & \multicolumn{3}{|c|}{ Full-time employees } & \multicolumn{3}{|c|}{ Part-time employees } & \multicolumn{3}{|c|}{ Total employees } \\
\hline & $\begin{array}{c}\text { Males } \\
\%\end{array}$ & $\begin{array}{c}\text { Females } \\
\%\end{array}$ & $\begin{array}{c}\text { Persons } \\
\%\end{array}$ & $\begin{array}{c}\text { Males } \\
\%\end{array}$ & $\begin{array}{c}\text { Females } \\
\%\end{array}$ & $\begin{array}{c}\text { Persons } \\
\%\end{array}$ & $\begin{array}{c}\text { Males } \\
\%\end{array}$ & $\begin{array}{c}\text { Females } \\
\%\end{array}$ & $\begin{array}{c}\text { Persons } \\
\%\end{array}$ \\
\hline Under $\$ 200$ & 0.6 & 0.4 & 0.5 & 41.9 & 29.7 & 32.9 & 6.6 & 14.0 & 10.1 \\
\hline$\$ 200$ and under $\$ 400$ & 3.9 & 4.7 & 4.2 & 27.6 & 31.3 & 30.4 & 7.4 & 17.1 & 11.9 \\
\hline$\$ 400$ and under $\$ 600$ & 14.1 & 22.2 & 17.0 & 15.8 & 23.3 & 21.3 & 14.4 & 22.7 & 18.3 \\
\hline$\$ 600$ and under $\$ 800$ & 23.5 & 29.6 & 25.7 & 5.5 & 7.9 & 7.3 & 20.9 & 19.5 & 20.3 \\
\hline$\$ 800$ and under $\$ 1,000$ & 17.5 & 17.5 & 17.5 & 2.9 & 3.3 & 3.2 & 15.4 & 10.9 & 13.3 \\
\hline$\$ 1,000$ and under $\$ 1,200$ & 13.9 & 12.2 & 13.3 & 1.5 & 1.4 & 1.5 & 12.1 & 7.2 & 9.8 \\
\hline$\$ 1,200$ and under $\$ 1,400$ & 8.2 & 5.9 & 7.4 & 0.9 & 0.6 & 0.7 & 7.1 & 3.5 & 5.4 \\
\hline$\$ 1,400$ and under $\$ 1,600$ & 5.0 & 2.4 & 4.0 & 0.5 & 0.3 & 0.3 & 4.3 & 1.4 & 3.0 \\
\hline$\$ 1,600$ and over & 10.7 & 3.9 & 8.3 & 1.3 & 0.2 & 0.5 & 9.3 & 2.2 & 6.0 \\
\hline No wage or salary & 2.6 & 1.1 & 2.1 & 1.9 & 1.9 & 1.9 & 2.5 & 1.5 & 2.0 \\
\hline Total & 100.0 & 100.0 & 100.0 & 100.0 & 100.0 & 100.0 & 100.0 & 100.0 & 100.0 \\
\hline
\end{tabular}

Source: (ABS 2005f, Cat, no. 6310.0)

Clare (2004) uses 2002 ABS Household Income and Labour Dynamics Australia (HILDA) unit record data to present the data given here in table 4. If we multiply the percentages for men and for women who have superannuation by their respective average balances we arrive at the estimated balance per man and woman by age group. These data are given in chart 6 . Chart 7 gives women's average balances as a percentage of those of men for each cohort. Clearly women in the younger cohorts, whose attachment to the labour force has increased over past decades, have larger percentage balances. Yet they still lag behind men's for the reasons noted above, namely women's disproportionate concentration in part-time and casual work and their child-bearing, child-rearing and care responsibilities that reduce their time and prospects in the paid labour force.

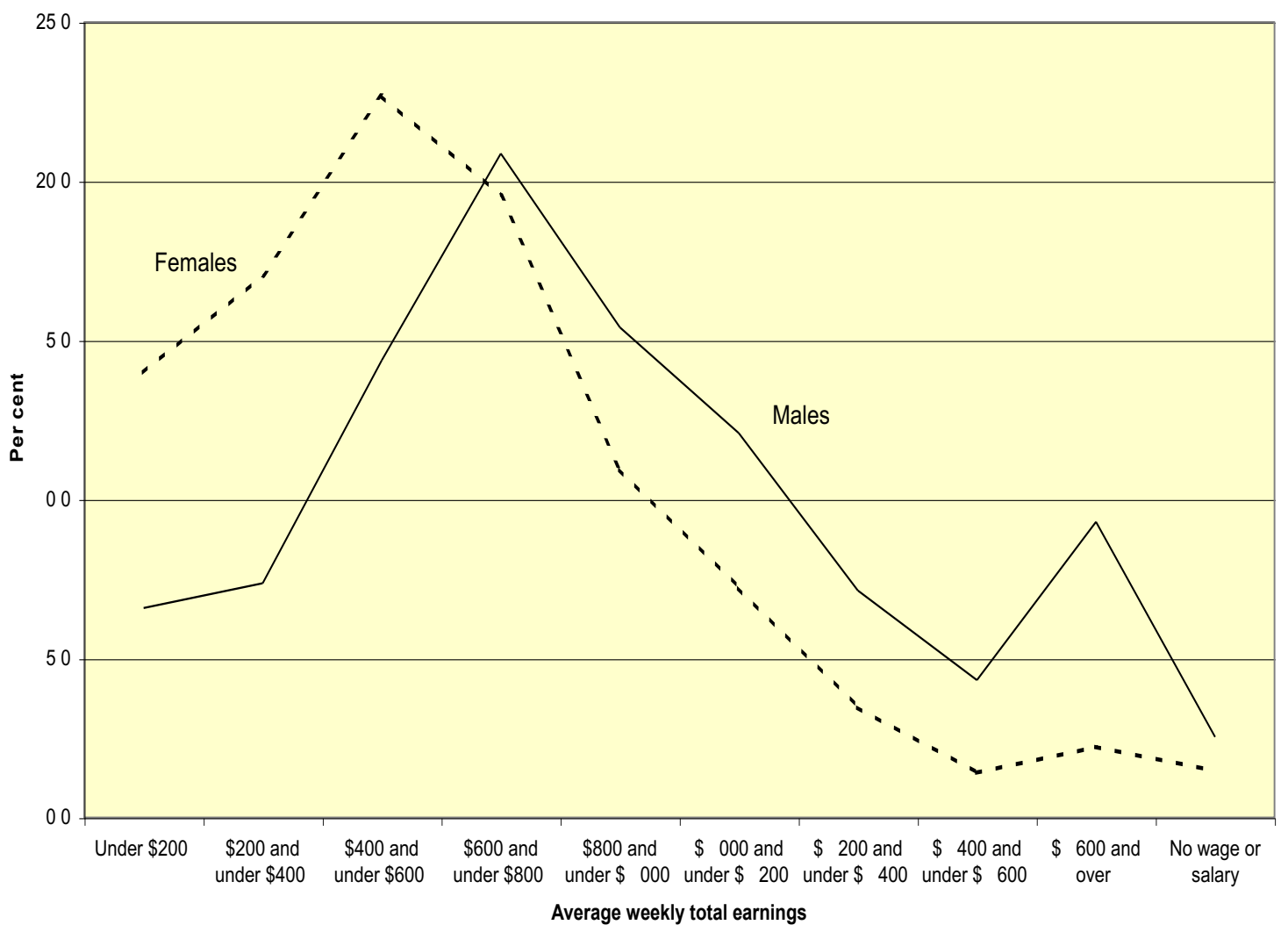

Chart 5: Superannuation coverage by average weekly earnings and gender Australia $2004 \$$ Source: (ABS 2005f, Cat, no. 6310.0) 
Table 4: Superannuation balances by age and gender Australia 2002 (HILDA)

\begin{tabular}{lcccc}
\hline Age cohort & $\begin{array}{c}\text { Men with } \\
\text { superannuation }\end{array}$ & $\begin{array}{c}\text { Average balances for } \\
\text { those with } \\
\text { superannuation }\end{array}$ & $\begin{array}{c}\text { Women with } \\
\text { Average balances for } \\
\text { superannuation }\end{array}$ & $\begin{array}{c}\text { with } \\
\text { superannuation }\end{array}$ \\
$15-24$ & 59.3 & 6,800 & 55.3 & $\$, 300$ \\
$25-34$ & 92.2 & 27,200 & 82.5 & 20,800 \\
$35-44$ & 91.7 & 65,400 & 78.3 & 37,600 \\
$45-54$ & 86.8 & 122,300 & 77.0 & 67,500 \\
$55-64$ & 68.8 & 183,600 & 53.4 & 94,700 \\
$65+$ & 26.6 & 184,900 & 12.6 & 124,300 \\
Total & 73.6 & 78,700 & 61.8 & 43,300 \\
\hline
\end{tabular}

Source: Clare (2004, p. 4), based on 2002 data from the ABS Household Income and Labour Dynamics Australia (HILDA) survey.

Chart 6: Average superannuation balances by age and gender Australia $2002 \$$

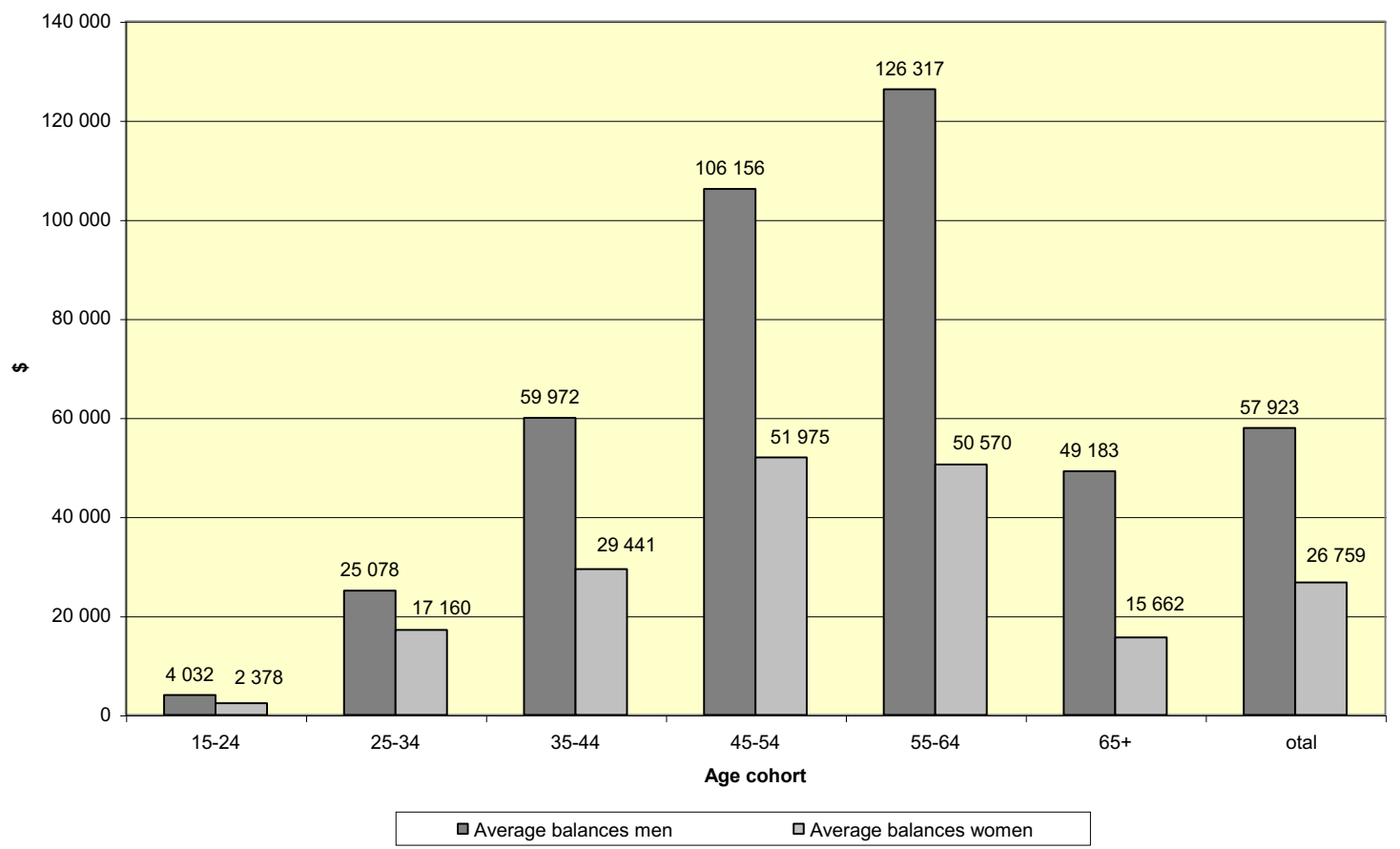

Source: Derived from Clare (2004, p. 4), based on 2002 data from the ABS Household Income and Labour Dynamics Australia (HILDA) survey. 
Chart 7: Women's average superannuation balances by age as per cent of men's Australia $2002 \%$

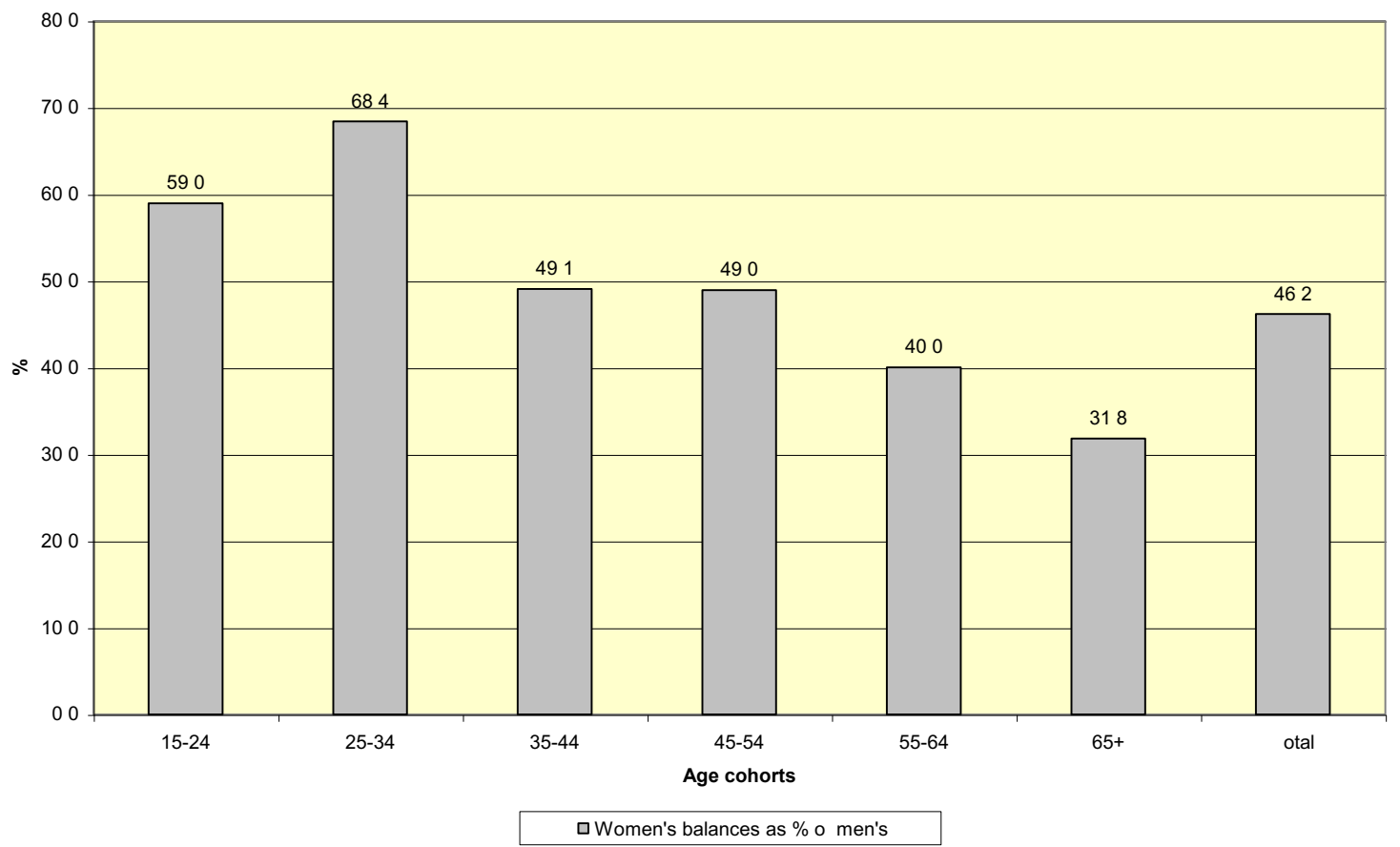

Source: Derived from Clare (2004, p. 4), based on 2002 data from the ABS Household Income and Labour Dynamics Australia (HILDA) survey.

\section{Dimensions of a Just Retirement Policy}

Is women's economic independence in retirement a mere pipe-dream? Let us make three very important points about the relationship between family income and the resources available to ageing women. First, many more women today are living independently, either by choice or because of divorce or separation from their partners. Second, women will 'need to accrue more superannuation savings than men to maintain a similar standard of living throughout their longer retirement years' (ABS 2002a). Third, women's status within their families is also a question of concern. Women's dependence is in part due to the smaller share of economic resources that they bring to the family and control within it (Sen 1999).

\section{(i) Policies focussing on women's paid and unpaid labour}

At any rate it seems clear to us that women's inequality in retirement derives from an unjust state of affairs for women leading to retirement. The first cause is that women's salaries are lower than men's are even when they work the same number of hours. This is not due to women working in industries and occupations that pay less, at least on a broad definition of industry and occupation (Doughney et al. 2003; Doughney 2004; Doughney \& Leahy 2005). Nor is the reason solely that women have career breaks for child-bearing and rearing and other care responsibilities. The main reason is that women occupy lower positions in organisations within industries and across occupations. This is what we must address, and it will require more radical affirmative-action remedies than have been contemplated to date in Australia.

Other causes - such as women's greater proportion of part-time and casual work and women's intermittent time in and out of the labour force (i.e. lower rate of participation) - themselves derive from, and can only be remedied if we start to challenge, women's disproportionate share of society's unpaid labour (Doughney et al. 2003). Nine-tenths of all unpaid labour comprises the various forms of household work, of which women's unpaid labour accounts for 65.8 per cent (compared with men's 
34.2 per cent). Women also do most of Australia's voluntary (including elder care) and community work (56.5 as against 43.5 per cent). Women account for 64.9 per cent of all unpaid household, voluntary and community work (as against 35.1 per cent for men). Women work on average 5 hours more per week than do men when we aggregate paid and unpaid working hours. Women who work similar hours to their partners still do 60.1 per cent of domestic work, compared with the 64.8 per cent of all domestic work that is done by women overall (Doughney et al. 2003).

Facts such as these cannot and should not be ignored. The data imply that women will spend less time in the paid workforce but do more hours of labour. The data also imply that women will continue to be concentrated in part-time and casual work in order to balance care responsibilities. The personal, economic and social impacts of the above social divisions of labour and earnings gaps are summarised well by Martha Nussbaum (1999, p. 135) in an American context that is also relevant in Australia:

The fact that women still are expected to perform most unpaid housework and childcare constrains women's access to employment and their productivity within it. It also contributes to a perception of women's lesser 'usefulness' and productivity that injures women's access to many opportunities and resources. As Susan Okin writes, summarizing a number of empirical studies, 'The perception that women's work is of less worth, largely because either unpaid or poorly paid (despite the fact that in most places they do more of it, and it is crucial to the survival of household members) contributes to women being devalued and having less power within the family and outside of the household' [Okin 1995, p. 284]. This perception, in turn, further reinforces women's economic dependence on men.

Such dependence will continue into retirement unless we contemplate radical policy measures that will affect women's position in society when they are younger. In addition to affirmative action at work, the following proposals by Grace, Leahy and Doughney (2005) address care responsibilities. The proposals comprised part of a response to the recent Striking the Balance project on work-family problems launched by Sex Discrimination Commissioner Pru Goward for the Human Rights and Equal Opportunity Commission. The proposals are:

1) A child-raising payment of a living wage to be paid in relation to all children under 3 years of age, and all persons requiring more than a certain threshold of caring work. This could be shared between parents and caregivers. It could be used to fund time out of the labour market or to enable labour market earning.

2) High quality affordable childcare for children under 3 years of age.

3) Free high quality childcare for children aged $3+$.

4) Free, high quality accessible out of school hours care, including suitable supervised programs for young people in the early years of secondary schooling

5) Generous training and retraining opportunities for parents who have spent time out of the labour market.

6) Adequate day programs for people with disabilities.

7) Adequate pay for people employed as carers in the market economy, reflecting the complexity and social importance of their work.

Though expensive, these policies merely 'bring hidden costs into the open and allocate them to those who benefit from the inputs'. As a society 'we cannot continue free riding on the labour of mothers and underpaid carers' (Grace, Leahy \& Doughney 2005).

\section{(ii) Policy proposals for women in retirement}

In addition to the above we propose that women's economic independence in part will depend on greater access to financial literacy education in order to plan for retirement. Moreover, short of the above 
radical prescriptions being adopted, women will be forced to rely on the age pension more than will men. Therefore two policy options open up:

1) To increase the age pension to ensure that women's economic wellbeing in retirement increases in the direction of those who have increasing superannuation entitlements.

2) Use the age pension to redress the discrimination women experience before retirement such that they are not further discriminated against in retirement because of their earlier disadvantage.

These proposals rest on evidence that (1) women are disadvantaged in both paid and unpaid labour and (2) that retirement incomes from superannuation are increasingly important for economic security and are a direct function of pre-retirement income.

\section{Conclusion}

The evidence this paper presents on women's positions in retirement and, especially regarding superannuation, leads to two key points. Firstly, women's disadvantage in retirement follows from women's disadvantaged position in the paid labour force. Secondly, women have the additional disadvantage of performing most of society's unpaid labour. This combination requires special remedies. A just retirement policy, which the paper has considered, must include special measures to redress women's previous unjust treatment. We propose a mix of superannuation-related and pension measures. Precisely how to articulate these measures in the context of Australia's changing economic, taxation, and ageing policy is the challenge for future research. One thing we do say to encourage researchers in this field is that they should not lose themselves in the web of complex policy practicalities. Important though the practicalities are, researchers must see through them so that they can keep their eyes on the vision of justice that should guide their endeavours.

\section{References}

ABS [Australian Bureau of Statistics] 2006, Year Book Australia, Cat. no. 1310.0, [online] http://abs.gov.au/AUSSTATS/abs@.nsf/Latestproducts/1301.0Feature\%20Article62006?opendocu ment\&tabname $=$ Summary\&prodno $=1301.0 \&$ issue $=2006 \&$ num $=\&$ view [last access 11 June 2006], ABS, Canberra. 2005a, Measures of Australia's Progress: Summary Indicators, [online] http://www.abs.gov.au/ausstats/abs@.nsf/94713ad445ff1425ca25682000192af2/29d20d8bb7d9a1b bca256fe4001293e4!OpenDocument [last access 20 October 2005], ABS, Canberra. 2005b, Year Book Australia, Cat. no. 1310.0, [online]

http://www.abs.gov.au/Ausstats/abs@.nsf/0/9895157A356ED97BCA256F7200832FEA?Open [last access 20 October 2005], ABS, Canberra.

2005c Labour Force, Australia, Cat. no. 6291.0.55.001, Detailed - Electronic Delivery_files,

ABS, Canberra. 2005d, Average Weekly Earnings, Australia, 6302.0, ABS, Canberra. 2005e, Household Income and Income Distribution, Australia, Cat. no. 6523.0, ABS, Canberra. 2005f, Employee Earnings, Benefits and Trade Union Membership, Australia, Cat, no. 6310.0,

ABS, Canberra. 2004a, Australian Demographic Statistics, Cat. no. 3101.0, ABS, Canberra. 2004b, Australian Historical Population Statistics, Cat. no. 3105.0.65.001, ABS, Canberra. 2003a, Year Book Australia: Feature Article - An ageing Australia, [online]

http://www.abs.gov.au/Ausstats/abs@.nsf/94713ad445ff1425ca25682000192af2/f6193189c8ad300 7ca256cae0005a250! OpenDocument [last access 20 October 2005], ABS, Canberra. 2003b, Population Projections, Australia, Cat. no. 3222.0, ABS, Canberra. 
2003c, Population by Age and Sex, Australian States and Territories, Cat. no. 3201.0, [online] http://www.abs.gov.au/ausstats/abs@.nsf/Lookup/AF3A416EB2791DCBCA25688D00098A09 [last access 21 November 2003], ABS, Canberra.

2003d, Australian Historical Population Statistics, Cat. no. 3105.0.65.001, [online] http://www.abs.gov.au/ausstats/abs@.nsf/Lookup/8EF64845AAC5B406CA256DAF0078B969 [last access 21/11/03], ABS, Canberra.

2002a, Australian Social Trends 2002: Income and Expenditure - Sources of Income: Employee superannuation, [online]

http://www.abs.gov.au/Ausstats/abs@.nsf/46d1bc47ac9d0c7bca256c470025ff87/a3832d7771e0b03 aca256bcd0082730c!OpenDocument [last access 20 October 2005].

2002b, Education and Work, Australia, Cat. no. 6227.0, [online]

http://www.ausstats.abs.gov.au/ausstats/subscriber.nsf/Lookup/949429E27A0D2403CA256C9200 7A340E/\$File/62270\%5Fmay\%202002.pdf [last access 1 December 2003] ABS, Canberra.

2001, Measuring Wellbeing: Frameworks for Australian Social Statistics, [online]

http://www.abs.gov.au/Ausstats/abs@.nsf/66f306f503e529a5ca25697e0017661f/f30663c90f8f455c ca256b5f0080421b!OpenDocument [last access 20 October 2005].

2001a, Superannuation: Coverage and Financial Characteristics, Australia, Cat no. 6360.0, ABS, Canberra.

2001b, Employment Arrangements and Superannuation, Australia, Cat. no. 6361.0, ABS, Canberra.

Australian Prudential Regulatory Authority 2005, Superannuation Trends, APRA Quarterly Survey of Superannuation, [online] http://www.apra.gov.au/Statistics/ [last access 11 June 20056, APRA, Canberra.

Bateman H, G Kingston and J Piggott (2001), Forced Saving, Cambridge University Press, Cambridge.

Clare, R 2004, 'Why can't a woman be more like a man: Gender differences in retirement savings', ASFA 2004 National Conference, Association of Superannuation Funds of Australia, Adelaide 1012 November.

Commonwealth Treasury of Australia (1999), 'The measurement of saving in Australia', Economic Roundup, pp 21-50.

Connolly, E \& M Kohler 2004, 'The impact of superannuation on household saving', Reserve Bank of Australia Research Discussion Paper, 2004-01.

Doughney J. \& J. King 2006, 'Crisis? What crisis? Myth and reality in the debate on an ageing Australia', People \& Place, vol. 14 no. 1, pp. 65-74.

Doughney, J. 2005, 'Ageing, employment and economic sustainability', refereed paper, Transitions and Risk: New Directions in Social Policy Conference, Centre for Public Policy, University of Melbourne, 23-25 February, 2005.

Doughney, J. 2004, 'Women and leadership in corporate Australia: Questions of preference and "adaptive preference", Advancing Women in Leadership Journal, (forthcoming).

Doughney, J \& M Leahy 2006, 'Women, work and the preference formation: A critique of Catherine Hakim's preference theory', Journal of Business Systems, Governance and Ethics, vol. 1 no. 1, pp. $37-48$.

Doughney, J, F Macdonald, J Pyke, A Lyon, M Leahy \& J Rea 2003, Lifelong Economic Wellbeing for Women: Obstacles and Opportunities, A study for the Security4Women consortium, Work and Economic Policy Research Unit, Victoria University, \& Access Training and Employment Centre, Melbourne.

Grace, M, M Leahy and J Doughney. 2005, 'Response to Striking the Balance: Women, Men, Work and Family' [online] http://www.humanrights.gov.au/sex\%5Fdiscrimination /strikingbalance/submissions/ [last access 11 June 2006]

Nussbaum, MC 2000, Women and Human Development: The Capabilities Approach, Cambridge University Press, Cambridge UK.

Okin, SM 1995, 'Inequalities between the sexes in different cultural contexts', in M Nussbaum \& J Glover eds. Women, Culture and Development, Clarendon Press, Oxford UK, pp. 274-97. 
Olsberg, D 2004, 'Women and Superannuation: Still MS...ing Out', Journal of Australian Political Economy, Special issue on superannuation, No. 53, pp.161-178.

Sen, A 1999, Development as Freedom, Oxford University Press, Oxford UK. 
